\title{
Reproductive biology of the sea cucumber Parastichopus parvimensis (Echinodermata: Holothuroidea) at Isla Natividad and Bahía Tortugas, Baja California Sur, Mexico
}

\section{Biología reproductiva del pepino de mar Parastichopus parvimensis (Echinodermata: Holothuroidea) de Isla Natividad y Bahía Tortugas, Baja California Sur, México}

\author{
MC Fajardo-León ${ }^{1 *}$, MCL Suárez-Higuera , A del Valle-Manríquez¹, A Hernández-López² \\ ${ }^{1}$ Centro Regional de Investigación Pesquera La Paz, BCS, Km 1 Carretera a Pichilingue, CP 23020, La Paz, Baja California Sur, \\ México.*E-mail: cfajardol@yahoo.com.mx \\ ${ }^{2}$ Centro Interdisciplinario de Ciencias Marinas (CICIMAR), Instituto Politécnico Nacional, La Paz, BCS, México.
}

\begin{abstract}
The reproduction of the sea cucumber Parastichopus parvimensis was studied from April 2000 to August 2001 at Isla Natividad and from March 2003 to March 2004 at Bahía Tortugas, Baja California Sur, Mexico. Samples were collected manually by semi-autonomous diving. The sea cucumber is a dioecious species, without external sexual dimorphism, with ramified gonad. The development of the gonad confirmed five stages: undifferentiated, gametogenesis, ripe, spawning, and postspawning; this indicated annual synchronous reproduction in both study areas. The sex ratio was 1:1. The variation of the gonadosomatic index was directly related to the gonadal development. Maximum maturity and spawning were recorded from February to May at both sites. The weight at first maturity was $140 \mathrm{~g}$ at Isla Natividad and $120 \mathrm{~g}$ at Bahía Tortugas. In both areas P. parvimensis showed seasonal visceral atrophy from August to October. As a fishery management alternative, we propose one closed season from February to May to protect the reproductive season (ripe/spawning), and another from August to October to protect the period when the internal organs are absent or atrophied.
\end{abstract}

Key words: reproductive cycle, gonadosomatic index, first maturity.

\section{Resumen}

Se estudió la reproducción del pepino de mar Parastichopus parvimensis en Isla Natividad (abril de 2000 a agosto de 2001) y Bahía Tortugas (marzo de 2003 a marzo de 2004), Baja California Sur, México. Las muestras se recolectaron manualmente por medio de buceo semiautónomo. Parastichopus parvimensis es una especie dioica, sin dimorfismo sexual externo, con gónada ramificada. El desarrollo de la gónada confirmó la existencia de cinco estadios: indiferenciado, gametogénesis, madurez, desove y post-desove. Se determinó un periodo de reproducción anual sincrónico en ambos sitios. La proporción de sexos fue 1:1. La variación del índice gonadosomático se relacionó directamente con el desarrollo gonadal. La máxima madurez y desove se registraron de febrero a mayo en ambos sitios de estudio. El peso de primera madurez fue $140 \mathrm{~g}$ en Isla Natividad y $120 \mathrm{~g}$ en Bahía Tortugas. En ambas áreas P. parvimensis presentó atrofia estacional de vísceras, de agosto a octubre. Como alternativa de manejo pesquero se propone una época de veda de febrero a mayo, para proteger el evento de reproducción (madurez y desove) y otra de agosto a octubre para salvaguardar el periodo de ausencia y/o atrofia de órganos internos.

Palabras clave: ciclo reproductor, indice gonadosomático, primera madurez.

\section{Introduction}

The sea cucumber Parastichopus parvimensis (Clark 1913) is an echinoderm of the class Holothuroidea, order Aspidochirota, represented by the family Stichopodiidae. It is distributed from Monterey Bay, California, USA, to Bahía Tortugas, Baja California Sur, Mexico. It inhabits temperate waters, from shallow areas to $40 \mathrm{~m}$ depth, on rocky, stony or sandy bottoms, where it promotes physicochemical changes as a result of sediment ingestion and substrate enrichment by deposits (Yingst 1976, 1982). This species undergoes seasonal absence and/or atrophy of viscera (digestive tract, respiratory tree, gonad), or they are only slightly developed.

\section{Introducción}

El pepino de mar Parastichopus parvimensis (Clark 1913) es un equinodermo de la clase Holothuroidea, orden Aspidochirota, representada por la familia Stichopodiidae. Se distribuye desde Monterey Bay, California, EUA, hasta Bahía Tortugas, Baja California Sur, México. Habita aguas templadas, desde zonas someras hasta $40 \mathrm{~m}$ de profundidad, sobre fondos rocosos, pedregosos y arenosos, en donde promueve cambios fisicoquímicos por la ingestión del sedimento y por el enriquecimiento del sustrato por sus deposiciones (Yingst 1976, 1982). Esta especie presenta ausencia y/o atrofia estacional de vísceras (tracto digestivo, árbol respiratorio, gónada) o están poco desarrolladas. 
Parastichopus parvimensis is one of the most important commercial species on the northwestern coast of the Baja California Peninsula, its area of distribution in Mexico. From 1988 to 2000 it was caught commercially exclusively in the state of Baja California, but its high demand and price in Asian markets, as well as the lack of regulations led to the overexploitation of this resource (Tapia-Vázquez et al. 1996). From May 2000 to May 2004 it was caught under a special fisheries scheme (pesca de fomento) in order to attain greater knowledge of its population biology since little research has been conducted on this species in Mexico. Studies on its reproductive cycle and growth were carried out in Baja California (PérezPlascencia 1995, Tapia-Vázquez et al. 1996). In Baja California Sur (BCS), studies have been conducted on abundance indices (Centro Regional de Investigación Pesquera-La Paz, Instituto Nacional de Pesca) and distribution of the species in the state (Fajardo-León and Turrubiates-Morales 2005), as well as on gonadal development based on morphochromatic observations and some aspects of growth (Espinoza-Montes 2000); however, research is lacking on the reproductive biology of the species in BCS to be able to propose and complement management criteria (Conand 1981, Cameron and Fankboner 1986). Considering that this species has been caught commercially in BCS since May 2004, this study aims to describe gonadal development, period and biological aspects of the reproduction of $P$. parvimensis, and to propose appropriate management strategies for its sustainable commercial exploitation and contribute to the state's fishery management plan.

\section{Material and methods}

\section{Study area}

Individuals of $P$. parvimensis were obtained from Isla Natividad (IN) and Bahía Tortugas (BT), BCS, Mexico (fig. 1).

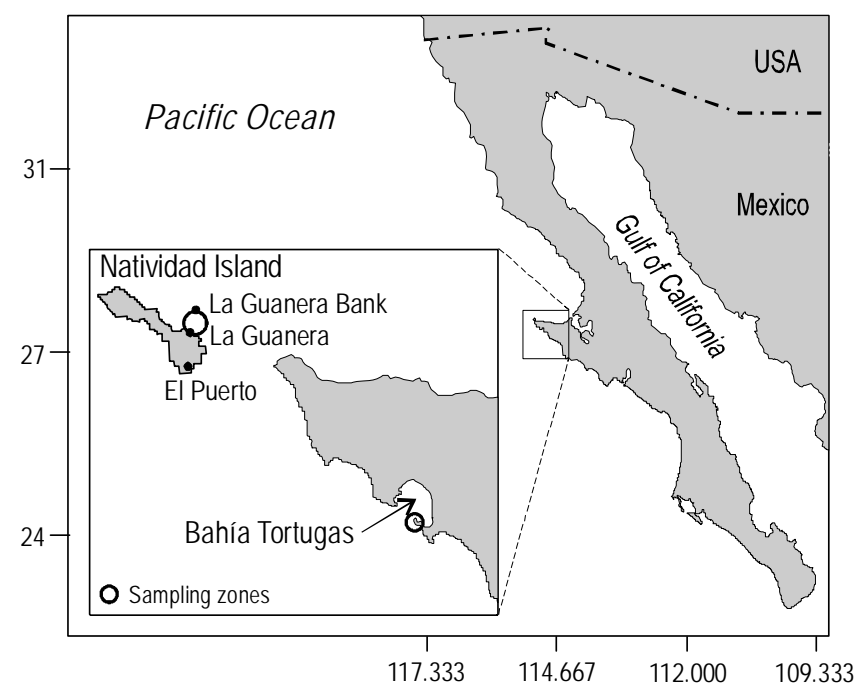

Figure 1. Study areas and sampling sites in Baja California Sur, Mexico. Figura 1. Áreas de estudio y zonas de muestreo en Baja California Sur, México.
Por su demanda y precio en el mercado asiático, $P$. parvimensis es es una de las principales especies de importancia comercial en la costa noroeste de la Península de Baja California, zona de distribución de la especie en México. De 1988 a 2000 su captura comercial se realizaba exclusivamente en el estado de Baja California. Su gran demanda y alto precio en el mercado asiático, aunados a la falta de reglamentación, originaron la sobreexplotación del recurso en Baja California (Tapia-Vázquez et al. 1996), por lo que de mayo de 2000 a mayo de 2004 su captura fue restringida al régimen de "pesca de fomento" con el fin de aumentar el conocimiento biológicopoblacional del recurso. Se han realizado pocos estudios sobre esta especie en el país. Entre ellos, en Baja California se han hecho algunos estudios sobre su ciclo reproductor y crecimiento (Pérez-Plascencia 1995, Tapia-Vázquez et al. 1996), mientras que en Baja California Sur (BCS) se han realizado investigaciones principalmente sobre índices de abundancia (Centro Regional de Investigación Pesquera-La Paz, Instituto Nacional de Pesca) y distribución de la especie en el estado (Fajardo-León y Turrubiates-Morales 2005), así como sobre el desarrollo gonádico por medio de observaciones morfocromáticas y algunos aspectos de crecimiento (Espinoza-Montes 2000). Sin embargo, en BCS no se han realizado investigaciones sobre la biología reproductiva de la especie para sugerir y complementar criterios de manejo (Conand 1981, Cameron y Fankboner 1986). Considerando que esta especie se captura ya comercialmente en BCS desde mayo de 2004, el objetivo del presente estudio fue describir el desarrollo gonádico, periodo y aspectos biológicos de la reproducción de $P$. parvimensis, para proponer estrategias de manejo para su aprovechamiento comercial responsable y sustentable y contribuir con el plan de manejo de la especie en el estado.

\section{Materiales y métodos}

Área de estudio

Este estudio se realizó en Isla Natividad (IN) y Bahía Tortugas (BT), BCS, México (fig. 1). Las zonas de muestreo fueron, en IN la localidad conocida como La Guanera (27 $52^{\prime} \mathrm{N}$,

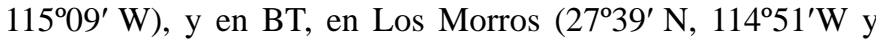
$\left.27^{\circ} 42^{\prime} \mathrm{N}, 114^{\circ} 54^{\prime} \mathrm{W}\right)$, ambas localidades con sustrato arenoso, rocoso y grava.

\section{Recolección de muestras}

Las muestras en IN se recolectaron mensualmente de abril de 2000 a agosto de 2001 y en BT de marzo de 2003 a marzo de 2004. La recolección de muestras en ambas zonas fue manual, por medio de buceo semiautónomo, entre 4 y 10 m de profundidad. Se aplicó el método de búsqueda abierta, sin transectos, ni unidad de muestreo determinada (Pérez-Ruzafa y Marcos-Diego 1985, Espinoza-Montes 2000). En ambas zonas, el tamaño medio de muestra varió entre 40 y 50 individuos por mes. Los organismos se colocaron individualmente en bolsas 
The sampling site at IN is known as La Guanera $\left(27^{\circ} 52^{\prime} \mathrm{N}\right.$,

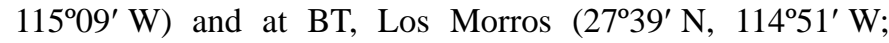
$\left.27^{\circ} 42^{\prime} \mathrm{N}, 114^{\circ} 54^{\prime} \mathrm{W}\right)$. Both sites have sandy, gravel and rocky substrates.

\section{Sample collection}

Samples were collected monthly from April 2000 to August 2001 at IN and from March 2003 to March 2004 at BT. All samples were collected manually by semi-autonomous diving between 4 and $10 \mathrm{~m}$ depth. The open search method was applied, without transects or specific sampling unit (PérezRuzafa and Marcos-Diego 1985, Espinoza-Montes 2000). At both sites sample size varied from 40 to 50 individuals per month. The organisms were individually placed in plastic bags to avoid the loss of viscera on handling. Small inicisions were made to the bags and they were placed in a plastic box with water for transportation to the laboratory.

\section{Morphometry}

The organisms were left to rest for 30 min to allow them to relax and recover their habitual dimensions. The following measurements were then taken: total length (TL), using a flexible 1-m tape measure; total wet weight (TW), without water, including tegument and internal organs; wet body wall weight (BW), without water or internal organs; and wet gonad weight (GW), using a digital scale (0.1-g precision). The length and weight data were grouped by sex and study site to determine the basic statistics (mean, standard deviation, and maximum and minimum values). An exploratory analysis was made of the biometric data (total length and weight) by sex and study site to obtain the descriptive statistics (mean, standard deviation, and maximum and minimum values).

\section{Histological process}

The gonads were removed from each animal and dissected, and the anatomy, colour, and wet weight were recorded. They were fixed in Davidson's solution (Bell and Lighter 1988) for $72 \mathrm{~h}$ and, after removing the solution, preserved in ethyl alcohol (70\%) until processing (Bell and Lighter 1988, MuñetónGómez et al. 2000).

The histological analysis of the gonadal tissue $(2 \mathrm{~g})$ was performed following the dehydration, clarifying and impregnation techniques. Sections 6-7 $\mu \mathrm{m}$ in thickness were made with a rotating microtome. The preparations were stained with hematoxylin-eosin (Grant y Tyler 1983) and mounted with synthetic resin (Bell and Lighter 1988, Martoja and Martoja 1970).

\section{Qualitative reproductive analysis}

The structure of the gonad was examined under a microscope based on the cellular characteristics of the nucleus, de plástico para evitar la pérdida de vísceras al ser manipulados. A las bolsas se les hicieron pequeñas incisiones y se pusieron en una caja de plástico con agua para su traslado al laboratorio.

\section{Morfometría}

Los individuos se dejaron reposar 30 min para su relajación y que recuperaran sus dimensiones habituales. Posteriormente, se midió su longitud total (LT) con cinta métrica flexible de 1 $\mathrm{m}$, el peso húmedo total (PT) (sin agua, incluyendo tegumento y órganos internos), peso húmedo de la pared del cuerpo (PC) (sin agua, ni órganos internos) y el peso húmedo de la gónada (PG), con una balanza digital de $0.1 \mathrm{~g}$ de precisión. Los datos de longitud y peso se agruparon por sexo y área de estudio obteniendo los estadísticos básicos (promedio, desviación estándar, máximo y mínimo). Se realizó un análisis exploratorio de los datos biométricos (longitud total y peso) por sexo y área para obtener la estadística descriptiva (promedio, desviación estándar, máximo y mínimo).

\section{Proceso histológico}

Se extrajo la gónada de cada animal, las cuales fueron disectadas registrando su anatomía, color, y peso húmedo. Posteriormente se fijaron en solución Davidson (Bell y Lighter 1988) durante 72 h, se eliminó la solución fijadora y se transfirieron a alcohol etílico al 70\% para su conservación hasta el procesamiento (Bell y Lighter 1988, Muñetón-Gómez et al. 2000).

El proceso histológico del tejido gonádico (2 g) fue realizado de acuerdo con las técnicas de deshidratación, aclaración e impregnación. Se hicieron cortes entre 6 y $7 \mu \mathrm{m}$ de espesor con un microtomo de rotación manual. Las preparaciones fueron teñidas con hematoxilina-eosina (Grant y Tyler 1983) y se montaron con resina sintética (Bell y Lighter 1988, Martoja y Martoja 1970).

\section{Análisis reproductor cualitativo}

La estructura de la gónada fue examinada bajo un microscopio óptico, y con base en las características celulares distintivas del núcleo, el citoplasma, la pared del epitelio folicular y el germinal, se establecieron las fases o estadios de desarrollo gonádico. El ciclo reproductor se definió con base en el reconocimiento y descripción de los tipos célulares de la gónada de acuerdo con los criterios utilizados por Cameron y Fankboner (1986) y Conand (1993a, b). Con la información generada se obtuvo el porcentaje y la frecuencia mensual de los estadios gonádicos por sexo, en cada zona.

\section{Análisis estadístico}

El peso de primera madurez sexual $\left(\mathrm{BW}_{50}\right.$, por sus siglas en inglés) se obtuvo utilizando las frecuencias acumuladas 
cytoplasm, follicular wall, and germinal epithelium, and the phases or stages of gonadal development were determined. The reproductive cycle was defined based on the examination and description of the gonadal cell types according to the criteria used by Cameron and Fankboner (1986) and Conand (1993a, b). With the information obtained, the monthly frequency and percentage of the gonadal stages was determined per sex and site.

\section{Statistical analysis}

Weight at first maturity $\left(\mathrm{BW}_{50}\right)$ was obtained using the relative cumulative frequencies of the BW (Conand 1993a) of mature individuals (stages III and IV).

To determine the sex ratio of $P$. parvimensis, the percentage of males, females, and undifferentiated organisms observed at each site was first plotted. The chi-square goodness-of-fit test (Sokal and Rohlf 1995) was then applied, comparing the observed and expected frequency of occurrence values for males and females, to verify whether the sex ratio at both sites was $1: 1$.

A monthly mean of the gonadosomatic index (GI) was calculated by sex and site, using the following equation: $\mathrm{GI}=(\mathrm{GW} / \mathrm{TW} \times 100)($ Conand 1990$)$.

Water temperature was only recorded at BT using a thermometer of $0.1^{\circ} \mathrm{C}$ precision, and it was related to the GI monthly mean.

\section{Results}

A total of 688 individuals from IN and 584 from BT were measured and weighed. At IN, the mean values were $22.1 \pm$ $6.0 \mathrm{~cm} \mathrm{TL}, 267 \pm 63 \mathrm{~g} \mathrm{TW}, 150.1 \pm 24.6 \mathrm{~g} \mathrm{BW}$, and $11.3 \pm$ $7.6 \mathrm{~g} \mathrm{GW}$ (table 1). At BT, the mean values were $20.3 \pm 2.6 \mathrm{~cm}$ TL, $206.0 \pm 50 \mathrm{~g}$ TW, $104.5 \pm 25.1 \mathrm{~g} \mathrm{BW}$, and $9.0 \pm 7.9 \mathrm{~g} \mathrm{GW}$ (table 1). The number of organisms decreased from August to October since the individuals occupied poorly accessible areas and were difficult to find. During these months, between 14 and 18 individuals with atrophied internal organs and without a gonad were collected.

The histological analysis was performed on 413 gonads from IN (35\% females, $40 \%$ males, and $25 \%$ undifferentiated) and 365 from BT (36\% females, $41 \%$ males, and 23\% undifferentiated). At IN, the mean values for females and males were $21.8 \pm 4.4$ and $21.9 \pm 4.3 \mathrm{~cm}$ TL, $275.6 \pm 101.5$ and $280.1 \pm$ $110.2 \mathrm{~g}$ TW, $143.3 \pm 42.3$ and $144.3 \pm 49.7 \mathrm{~g} \mathrm{BW}$, and $15.6 \pm$ 17.1 and $13.4 \pm 12.0 \mathrm{~g} \mathrm{GW}$, respectively (table 1 ). At BT, the mean values for females and males were $20.2 \pm 3.1$ and $20.6 \pm$ $2.8 \mathrm{~cm}$ TL, $219.9 \pm 62.1$ and $221.5 \pm 51.7 \mathrm{~g}$ TW, $103.3 \pm 25.3$ and $105.1 \pm 22.6 \mathrm{~g} \mathrm{BW}$, and $9.8 \pm 9.4$ and $93.5 \pm 6.2 \mathrm{~g} \mathrm{GW}$, respectively (table 1 ).

\section{Sex ratio and percentage}

The monthly percentages of the sexually differentiated and undifferentiated organisms and the period when the gonad was relativas del PC (Conand 1993a) de los individuos maduros (estadios III y IV).

Para conocer la proporción de sexos en $P$. parvimensis primero se graficó el porcentaje observado de hembras, machos e indiferenciados, en cada zona. Después se aplicó la prueba $\chi^{2}$ de bondad de ajuste (Sokal y Rohlf 1995), comparando los valores observados y esperados de frecuencia de ocurrencia de hembras y machos, para verificar si la proporción de sexos en ambos sitios de estudio era 1:1.

Se calculó un promedio mensual del índice gonadosomático (IG) por sexo y zona, a partir de la ecuación: $I G=(P G / P T$ $\times$ 100) (Conand 1990).

Se registró la temperatura del agua durante el muestreo únicamente en $\mathrm{BT}$, con un termómetro de precisión $0.1^{\circ} \mathrm{C}$, y se relacionó con el promedio mensual del IG.

\section{Resultados}

Se midieron y pesaron 688 individuos de IN y 584 de BT. En IN los promedios fueron: $22.1 \pm 6.0 \mathrm{~cm}$ de LT, $267 \pm 63 \mathrm{~g}$ de PT, $150.1 \pm 24.6$ g de PC y $11.3 \pm 7.6$ g de PG (tabla 1$)$. En BT los promedios fueron $20.3 \pm 2.6 \mathrm{~cm}$ de LT, $206.0 \pm 50 \mathrm{~g}$ de PT, $104.5 \pm 25.1$ g de PC y $9.0 \pm 7.9$ g de PG (tabla 1 ). La disponibilidad de organismos se redujo de agosto a octubre debido a que los individuos se encontraron en lugares poco accesibles, lo que dificultó su localización. En estos meses se recolectaron entre 14 y 18 individuos con atrofia de órganos internos y sin gónada por zona.

Se analizaron histológicamente 413 gónadas provenientes de IN (35\% hembras, $40 \%$ machos y $25 \%$ indiferenciados) y 365 de BT (36\% hembras, 41\% machos y 23\% indiferenciados). En IN los promedios respectivos para hembras y machos fueron $21.8 \pm 4.4 \mathrm{~cm}$ y $21.9 \pm 4.3 \mathrm{~cm}$ de LT, $275.6 \pm 101.5 \mathrm{~g} \mathrm{y}$ $280.1 \pm 110.2$ g de PT, $143.3 \pm 42.3$ g y $144.3 \pm 49.7$ g de PC, $y$ $15.6 \pm 17.1$ g y $13.4 \pm 12.0$ g de PG (tabla 1$)$. En BT los promedios respectivos para hembras y machos fueron $20.2 \pm 3.1$ cm y $20.6 \pm 2.8 \mathrm{~cm}$ de LT, $219.9 \pm 62.1 \mathrm{~g}$ y $221.5 \pm 51.7 \mathrm{~g}$ de PT, $103.3 \pm 25.3$ g y $105.1 \pm 22.6$ g de PC, y $9.8 \pm 9.4$ g y 93.5 $\pm 6.2 \mathrm{~g}$ de PG (tabla 1$)$.

\section{Porcentaje y proporción de sexos}

El porcentaje mensual de organismos sexualmente diferenciados e indiferenciados y la época de ausencia estacional de la gónada por área de estudio se presentan en la figura 2. La prueba $\chi^{2}$ indicó que la distribución observada de la proporción de hembras y machos no fue significativamente diferente de la distribución esperada, por lo que se asumió una proporción de sexos de 1:1 en ambas zonas de estudio (IN: $\chi^{2}=22.8$, g.l. $=$ 12, $P>0.05$; BT: $\chi^{2}=15.4$, g.l. $=9, P>0.05$ ).

\section{Morfología de sexos y descripción gonadal}

En P. parvimensis los sexos están separados; no hay dimorfismo sexual externo. A la disección se observó la gónada 
Table 1. Mean total length (TL in cm), total weight (TW in g), body wall weight (BW in g), and gonad weight (GW in g) of Parastichopus parvimensis at Isla Natividad and Bahía Tortugas.

Tabla 1. Promedio (PM) de longitud total (TL en cm), peso total (TW en g), peso pared del cuerpo (BW en g) y peso de la gónada (GW en g) de Parastichopus parvimensis de Isla Natividad y Bahía Tortugas.

\begin{tabular}{|c|c|c|c|c|c|c|c|}
\hline Sampling site and dates & Total/sex & $\begin{array}{c}\text { No. of } \\
\text { specimens }\end{array}$ & Variable & Mean & $\begin{array}{l}\text { Standard } \\
\text { deviation }\end{array}$ & Minimum & Maximum \\
\hline Isla Natividad & Total & 688 & TL & 22.1 & 6.0 & 9 & 40 \\
\hline \multirow[t]{11}{*}{ April 2000-August 2001} & & 688 & TW & 267.0 & 63.3 & 80 & 775 \\
\hline & & 688 & BW & 150.1 & 24.6 & 55 & 326 \\
\hline & & 512 & GW & 11.3 & 7.6 & $<1$ & 132 \\
\hline & Females & 196 & $\mathrm{TL}$ & 21.8 & 4.4 & 11 & 40 \\
\hline & & 196 & TW & 275.6 & 101.5 & 104 & 791 \\
\hline & & 196 & BW & 143.3 & 42.3 & 72 & 326 \\
\hline & & 196 & GW & 15.6 & 17.1 & $<1$ & 132 \\
\hline & Males & 217 & TL & 21.9 & 4.3 & 10 & 39 \\
\hline & & 217 & TW & 280.1 & 110.2 & 102 & 775 \\
\hline & & 217 & BW & 144.3 & 49.7 & 75 & 360 \\
\hline & & 217 & GW & 13.4 & 12.0 & $<1$ & 74 \\
\hline Bahía Tortugas & Total & 584 & TL & 20.3 & 2.6 & 11 & 30 \\
\hline \multirow[t]{11}{*}{ March 2003-March 2004} & & 584 & TW & 206.0 & 50.0 & 48 & 471 \\
\hline & & 584 & BW & 104.5 & 25.1 & 18 & 212 \\
\hline & & 421 & GW & 9.0 & 7.9 & $<1$ & 54 \\
\hline & Females & 170 & $\mathrm{TL}$ & 20.2 & 3.1 & 10 & 30 \\
\hline & & 170 & TW & 219.9 & 62.1 & 74 & 471 \\
\hline & & 170 & BW & 103.3 & 25.3 & 52 & 212 \\
\hline & & 170 & GW & 9.8 & 9.4 & $<1$ & 54 \\
\hline & Males & 195 & $\mathrm{TL}$ & 20.6 & 2.8 & 13 & 27 \\
\hline & & 195 & TW & 221.5 & 51.7 & 136 & 399 \\
\hline & & 195 & BW & 105.1 & 22.6 & 56 & 170 \\
\hline & & 195 & GW & 9.5 & 6.2 & $<1$ & 33 \\
\hline
\end{tabular}

absent are shown per site in figure 2. The chi-square test indicated that the distribution observed in the proportion of males and females was not significantly different than the distribution expected, so a 1:1 sex ratio was assumed for both study sites (IN: $\chi^{2}=22.8$, d.f. $=12, P>0.05$; BT: $\chi^{2}=15.4$, d.f. $=9, P>0.05)$.

\section{Sex morphology and gonadal description}

Parastichopus parvimensis has separate sexes; there is no external sexual dimorphism. During dissection, the unpaired gonad was observed hanging freely in the anterior part of the coelomic cavity. It appears as a tubular structure, formed by bifurcate tubules, and the texture and colour depend on the degree of maturity, from transparent gelatinous (immature) to granular (maximum maturity). Tubules are shorter, thicker, and orange coloured in females, and thinner and cream coloured in males. impar colgando libremente en la parte anterior de la cavidad celómica. Morfológicamente tiene apariencia tubular racimosa, formada por túbulos bifurcados, y la textura y color dependió del grado de madurez, de transparente gelatinosa (inmadura) a granulosa (máxima madurez). En las hembras la gónada presentó túbulos más cortos y gruesos de color naranja, y en los machos los túbulos son más delgados y de color crema.

\section{Estadios de madurez}

Con base en las observaciones morfológicas e histológicas se describieron e identificaron cinco estadios de desarrollo para $P$. parvimensis de ambos sexos y áreas: indiferenciado, gametogénesis (desarrollo), madurez, desove y post-desove. En la figura $3(\mathrm{a}-\mathrm{h})$ se presentan los cinco estadios observados para hembras y machos.

- Estadio I. Indiferenciado o en reposo. Gónada cristalina, ramificada, poco desarrollada. Túbulos cortos (3-6 mm de 


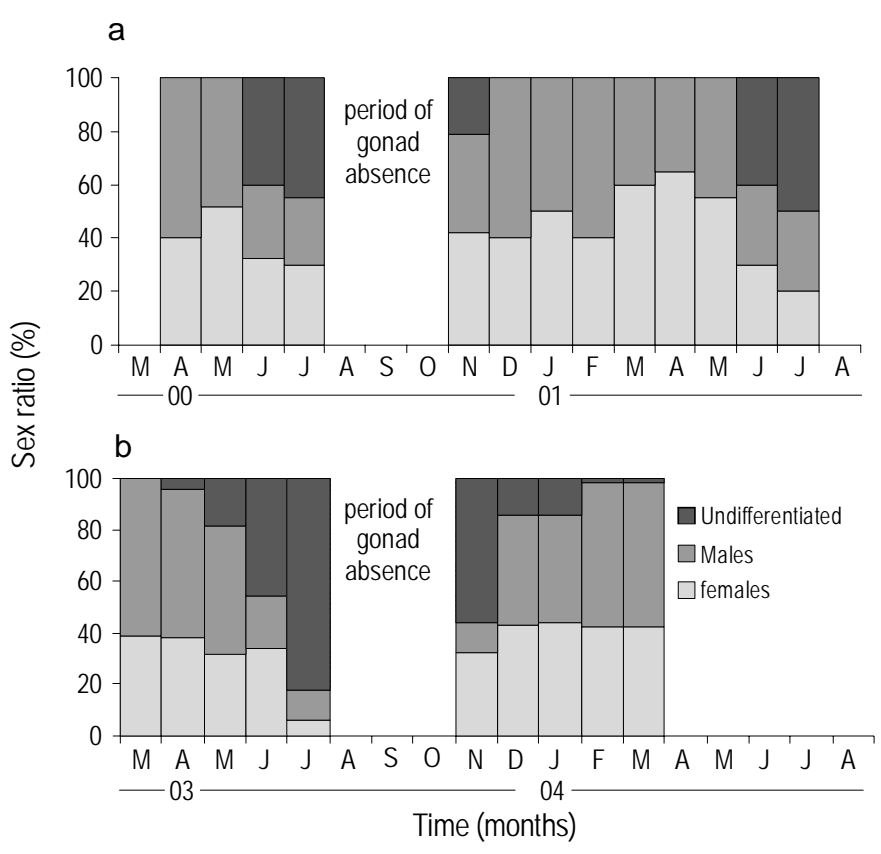

Figure 2. Percentage of female, male, and undifferentiated specimens of Parastichopus parvimensis per month and study site: (a) Isla Natividad (April 2000 to August 2001), and (b) Bahía Tortugas (March 2003 to March 2004).

Figura 2. Porcentaje de Parastichopus parvimensis hembras, machos e indiferenciados por mes y área de estudio: (a) Isla Natividad (abril de 2000 a agosto de 2001) y (b) Bahía Tortugas (marzo de 2003 a marzo de 2004).

\section{Maturity stages}

Based on the morphological and histological observations, five stages of development were identified and described for both sexes of $P$. parvimensis from both sites: undifferentiated, gametogenesis (developing), ripe, spawning, and postspawning (spent). Figure 3(a-h) shows the five stages observed for males and females.

- Stage I. Undifferentiated or in repose. Gonad crystalline, ramified, not well developed. Tubules short (3-6 mm in length) and thin (0.5-1 mm in diameter). The sex cannot be defined. Tubules contain a large amount of connective tissue with germinal cells. Gametes are not differentiated.

\section{Male stages}

- Gametogenesis (II). Gonad developing. Tubules off-white in colour, and increasing in length (3-6 mm) and diameter (0.5-1.5 mm). Tubule walls are thick and pleated. Spermatids heavily concentrated on the follicular walls. Gametes oriented towards the lumen (fig. 3a).

- Ripe (III). Cream-coloured gonad prominent. Tubules undergo maximum increase in length $(5-6 \mathrm{~cm})$ and diameter $(1.5-2 \mathrm{~mm})$. Lumen attains maximum diameter, with thin wall, full of mature spermatozoids, and no empty spaces (fig. 3b). longitud) y delgados (0.5-1 mm de diámetro). El sexo no se puede definir. En los túbulos hay una gran cantidad de tejido conectivo con células germinales, pero no se distinguen gametos.

\section{Estadios en machos}

- Gametogénesis (II). Gónada en desarrollo. Túbulos de color blanquecino, aumento de longitud (3-6 mm) y diámetro $(0.5-1.5 \mathrm{~mm})$. En esta etapa las paredes de los túbulos se ven gruesas y con pliegues. Gran concentración de espermátidas en los márgenes de las paredes del folículo, los gametos se orientan hacia el lumen (fig. 3a).

- Madurez (III). Gónada turgente color crema, aumento máximo en longitud (5-6 cm) y diámetro $(1.5-2 \mathrm{~mm})$ de los túbulos. El lumen alcanzó su máximo diámetro, con pared delgada, lleno de espermatozoides maduros, y no se observan espacios vacíos (fig. 3b).

- Desove (IV). Fase de liberación de gametos. Se observan espacios vacíos y las paredes de los túbulos se ven menos gruesas; esto se nota en el grado de intensidad con que se tiñeron las capas gaméticas (fig. 3c).

- Post-desove (V). Disminución de la longitud y diámetro de los túbulos elongados, los cuales se ponen flácidos y semicristalinos, la pared del lumen se encuentra rota (fig. 3d).

\section{Estadios en hembras}

- Gametogénesis (II). La gónada, en crecimiento, adquiere un color naranja pálido. La longitud y diámetro de los túbulos aumentó (2-4 cm y 1-2 mm, respectivamente). Folículos con epitelio germinal en proceso de proliferación celular. Gran producción de oogonias previtelogénicas, esféricas, unidas al epitelio por un pedúnculo. Núcleo con nucleolo periférico. Pared folicular gruesa con pliegues. Gran cantidad de tejido conectivo. Crecimiento celular hacia el lumen y presencia de acinis (fig. 3e).

- Madurez (III). Gónada con máximo volumen, turgente y de color naranja intenso. Túbulos de 5-8 $\mathrm{cm}$ de longitud y de 2-3 mm de diámetro. Acinis llenos, pared folícular delgada, no hay tejido conectivo, llenos de ovocitos vitelogénicos. No hay espacios vacíos ni en el lumen ni entre las células. Núcleo con tres nucleolos periféricos y citoplasma granuloso (fig. 3f).

- Desove (IV). Reducción del tamaño y diámetro de túbulos semivacíos. Gónada flácida y decolorada. Paredes foliculares engrosadas, formando pliegues. Lumen con grandes espacios vacíos. En esta fase los oocitos se liberan; los oocitos remanentes reducen tamaño y pierden forma (fig. 3g).

- Post-desove (V). Fase degenerativa. Folículos colapsados, casi vacíos, en reabsorción, con gran cantidad de tejido conectivo, la pared rota y de forma irregular con ovocitos aislados y amorfos (fig. 3 h). 
Males
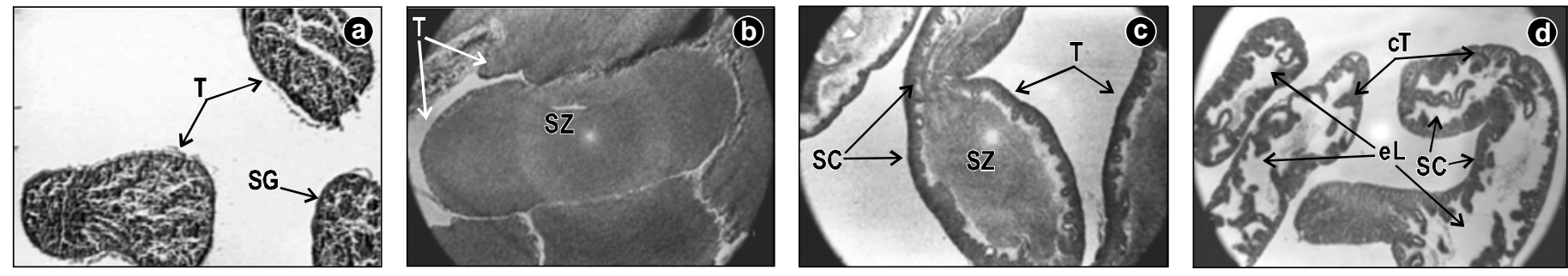

Females
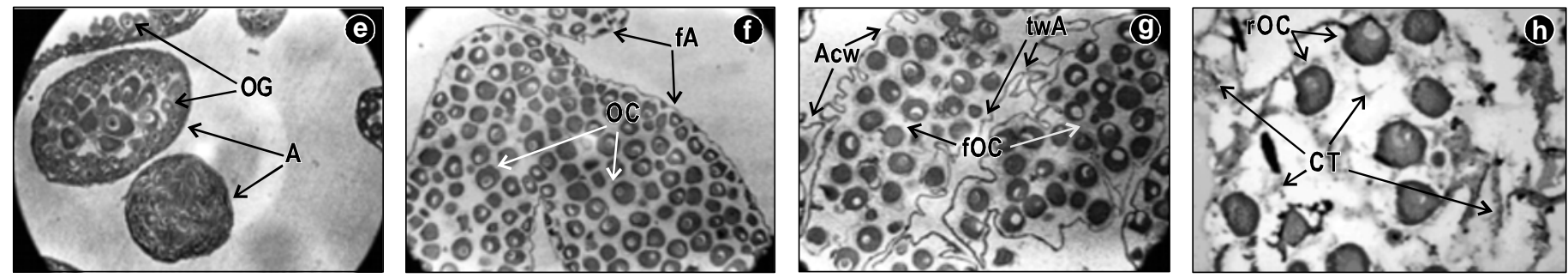

Figure 3. Gonadal development in Parastichopus parvimensis. Male and female stages: gametogenesis (a, e), ripe (b, f), spawning (c, $\mathbf{g})$, and post-spawning (d, h). Tubules (T), spermatogonia (SG), spermatocytes (SC), spermatozoids (SZ), collapsed tubules (cT), empty lumen (eL), acini (A), oogonia (OG), oocytes $(\mathrm{OC})$, full acini (fA), thin-walled acini (twA), free oocytes (fOC), collapsed walls of acini (Acw), remnant oocytes (rOC), and connective tissue (CT).

Figura 3. Desarrollo gonádico de Parastichopus parvimensis, en machos y hembras: gametogénesis $(\mathbf{a}, \mathbf{e})$, madurez (b, f), desove (c, g) y postdesove (d, h). Túbulos ( $T$ ), espermatogonias (SG), espermatocitos (SC), espermatozoides (SZ), túbulos colapsados (cT), lumen vacío (eL), acinis (A), oogonias (OG), oocitos (OC), acinis llenos (fA) y con paredes delgadas (twA), oocitos libres (fOC), paredes colapsadas del acini (Acw), oocitos remanentes (rOC), y tejido conectivo (CT).

- Spawning (IV). Gamete release phase. Empty spaces are observed and tubule walls appear less thick; this is determined by the degree of staining undergone by the gamete layers (fig. 3c).

- Post-spawning (V). Elongated tubules decrease in length and diameter, and become flaccid and semicrystalline. Lumen wall is broken (fig. 3d).

Female stages

- Gametogenesis (II). Gonad is growing and acquires a pale orange colour. The length and diameter of the tubules increases (2-4 cm and 1-2 mm, respectively). Follicles with germinal epithelium in the process of cell proliferation. Large production of previtellogenic, spherical oogonia, joined to the epithelium by a peduncle. Nucleus with peripheral nucleolus. Follicular wall thick and pleated. Large amount of connective tissue. Cell growth towards the lumen and presence of acini (fig. 3e).

- Ripe (III). Gonad is prominent, intensely orange in colour, and attains maximum volume. Tubules of $5-8 \mathrm{~cm}$ in length and $2-3 \mathrm{~mm}$ in diameter. Acini full, thin follicular wall, no connective tissue, full of vitellogenic oocytes. Empty spaces are not observed either in the lumen or between cells. Nucleus with three peripheral nucleoli and granular cytoplasm (fig. 3f).

- Spawning (IV). Reduction in size and diameter of semiempty tubules. Gonad flaccid and discoloured. Follicular

\section{Ciclo reproductor}

El ciclo reproductor de $P$. parvimensis en ambos sitios presentó un patrón anual para ambos sexos. El evento reproductor inició con la fase de gametogénesis, con máximos porcentaje de organismos en este estadio en IN y BT en noviembre ( $44 \%$ y $38 \%$, respectivamente) y diciembre ( $40 \%$ y $43 \%$, respectivamente) (fig. 4a, b). En IN los máximos porcentajes de madurez se presentaron en abril (59\%) de 2000, y febrero (65\%) y marzo $(70 \%)$ de 2001 , mientras que en $\mathrm{BT}$, sucedieron en marzo (60\%) y abril (50\%) de 2003, y en febrero (50\%) y marzo (60\%) de 2004 (fig. 4a, b). En ambas localidades el máximo desove se detectó en abril y mayo: en IN el porcentaje más alto fue en abril (55\%) y mayo (59\%) de 2000, y en mayo (65\%) de 2001, mientras que en BT éste fue en mayo (65\%) de 2003 (fig. 4a, b). El máximo post-desove tanto en IN como en BT ocurrió en junio (30-45\%) y julio (30-40\%) (fig. 4a, b), resultando el fin del periodo reproductivo. De agosto a octubre en ambas zonas no se registraron estadios gonádicos debido a que los individuos encontrados en estos meses no tenían gónada (fig. 4a, b). En estos meses los organismos evidenciaron también la ausencia y/o atrofia estacional de otros órganos internos (tracto digestivo, aparato circulatorio, etc). En noviembre los especímenes presentaron regeneración de órganos internos y gónada, marcando el reinicio el ciclo.

Los estadios mostraron una periodicidad anual, relacionada con las variaciones del IG en ambos sexos y áreas. El incremento del promedio mensual del IG, tanto en IN (hembras 4.3, 
walls thicker, forming pleats. Lumen with large empty spaces. Oocytes are released during this stage; those that remain decrease in size and lose their shape (fig. 3g).

- Post-spawning (V). Degenerative phase. Follicles collapsed, nearly empty, undergoing reabsorption, with a large amount of connective tissue, broken wall, and irregular shape with isolated and amorphous oocytes (fig. 3 h).

\section{Reproductive cycle}

An annual reproductive cycle was observed for both males and females of $P$. parvimensis at both sites. The cycle initiated with gametogenesis, and the maximum percentage of organisms in this stage at IN and BT was recorded in November (44\% and 38\%, respectively) and December (40\% and 43\%, respectively) (fig. 4a, b). At IN the maximum percentage of ripe organisms was found in April (59\%) 2000, and February (65\%) and March (70\%) 2001; at BT it was found in March (60\%) and April (50\%) 2003, and February (50\%) and March (60\%) 2004 (fig. 4a, b). Maximum spawning occurred in April and May at both sites: at IN the highest percentage was recorded in April (55\%) and May (59\%) 2000, and May (65\%) 2001, while at BT it was recorded in May (65\%) 2003 (fig. 4a, b). Maximum percentage of post-spawning specimens (end of the reproductive cycle) was recorded at both IN and BT in June (30-45\%) and July (30-40\%) (fig. 4a, b). Gonadal

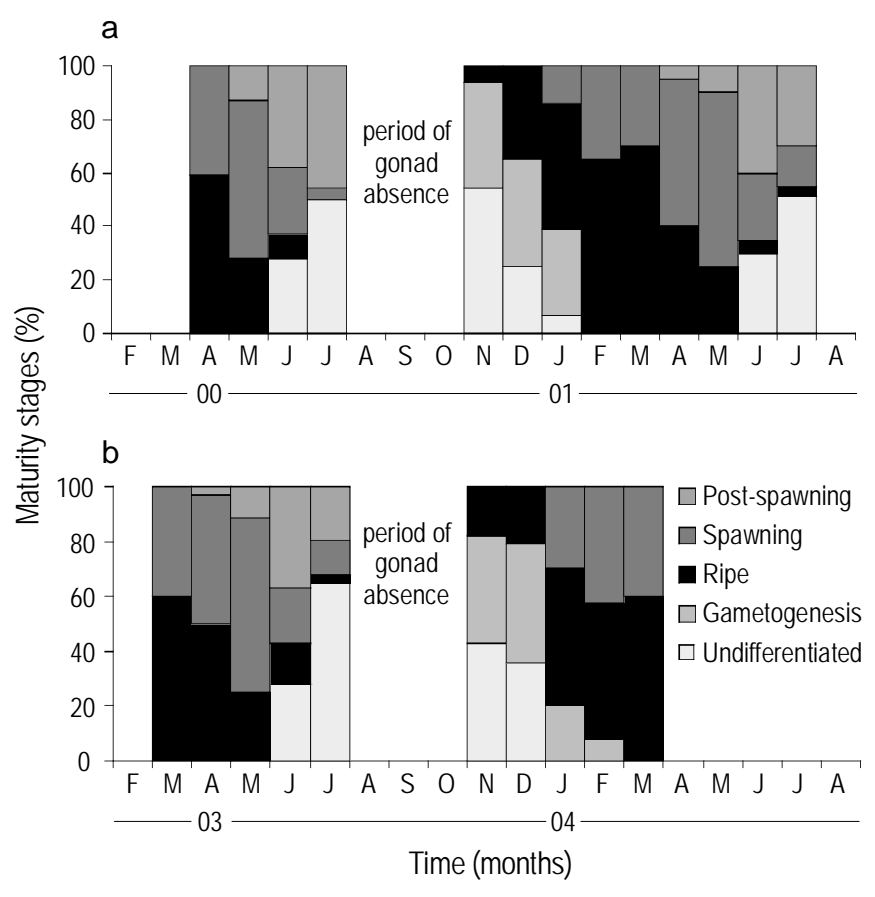

Figure 4. Monthly frequency of the maturity stages of Parastichopus parvimensis, including males and females: (a) Isla Natividad and (b) Bahía Tortugas.

Figura 4. Frecuencia mensual de los estadios de madurez de Parastichopus parvimensis, incluyendo hembras y machos: (a) Isla Natividad y (b) Bahía Tortugas. machos 4.6) como en BT (hembras 4.5, machos 4.0) inicio en noviembre (fig. $5 \mathrm{a}, \mathrm{b}$ ). La gónada madura representó un alto porcentaje del peso corporal. El IG medio máximo en IN se presentó en abril (hembras 5.5, machos 5.0) de 2000 y marzo (hembras 11.0, machos 10.0) y abril (hembras 9.0, machos 8.5) de 2001, mientras que en BT éste se presentó en marzo (hembras 7.5, machos 6.8) de 2003, y febrero (hembras 6.2, machos 6.0) y marzo (hembras 6.6, machos 6.0) de 2004. En mayo los promedios de IG en ambos sexos y zonas disminuyeron (fig. 5a, b). Los valores más bajos de IG se registraron en junio y julio (IG $=2$ ) (fig. 5a, b). De agosto a octubre el promedio de IG fue cero para ambos sexos en ambas áreas (fig. 5a, b).

\section{Peso de primera madurez}

El peso de primera madurez (cuando el 50\% de los individuos de la población presentaron la gónada madura), para ambos sexos fue de $140 \mathrm{~g}$ en IN y de $120 \mathrm{~g}$ en BT (fig. 6a, b).

\section{Temperatura}

En IN no fue posible registrar la temperatura en la zona de muestreo. En BT la temperatura en la zona de muestreo varió estacionalmente y presentó una relación inversa con IG. La temperatura máxima $\left(23.0^{\circ} \mathrm{C}\right)$ se registró en octubre y la mínima $\left(14^{\circ} \mathrm{C}\right)$ en abril (fig. 5b).

\section{Discusión}

En los holotúridos es difícil medir la longitud debido a la capacidad que tienen para contraerse y distenderse con facilidad, la ausencia de un esqueleto y su pared corporal blanda. Estas características se constataron en $P$. parvimensis que, aunque se dejaron reposar 30 min en el laboratorio para que recuperaran su tamaño habitual, esto no fue de utilidad pues los individuos continuaron cambiando su longitud ante cualquier estímulo dificultando su medición (Conand 1990, 1993b; Wiedemeyer 1994; Pérez-Plascencia 1995; Espinoza-Montes 2000). En el presente estudio, la longitud y el peso total sólo fueron tomados como referencia de la talla y peso total de los organismos muestreados, por lo que no se hizo un análisis profundo de estas variables. La longitud de P. parvimensis no es una medida recomendable como para implementar y aplicar una talla mínima de captura como táctica de manejo, ya que ésta no seríala mejor opción (Pérez-Ruzafa y Marcos-Diego 1985, Conand 1990).

Por otra parte, PC es una variable precisa y confiable porque, independientemente de la forma y tamaño que adquirieron los individuos, su variación fue mínima entre sexos y zonas. Comparando los promedios de PC en IN entre hembras y machos no se observó diferencia significativa, al igual que sucedió en ambos sexos en BT; sin embargo, los promedios de PC en IN resultaron ligeramente mayores a los de BT. Actualmente PC es la variable biométrica más utilizada en estudios de biología reproductiva y dinámica poblacional de holotúridos, 
stages were not observed from August to October at both sites, since the gonad was absent in all the individuals collected during that period (fig. 4a, b). During those months the organisms also underwent seasonal absence and/or atrophy of other internal organs (digestive tract, circulatory system, etc). In November the specimens showed regeneration of the internal organs and gonad, reinitiating the cycle.

The stages presented an annual periodicity, related to variations in the GI of both sexes and sites. The mean monthly GI values began to increase in November, both for IN (females 4.3, males 4.6) and BT (females 4.5, males 4.0) (fig. 5a, b). The mature gonad represented a high percentage of the body weight. The maximum mean GI values for IN occurred in April (females 5.5, males 5.0) 2000, and March (females 11.0, males 10.0) and April (females 9.0, males 8.5) 2001, while those for BT occurred in March (females 7.5, males 6.8) 2003, and February (females 6.2, males 6.0), March (females 6.6, males 6.0) 2004. The mean GI values for both sexes and sites decreased in May (fig. 5a, b). The lowest GI values were recorded in June and July (GI = 2) (fig. 5a, b). From August to October the mean GI value was zero for both sexes and sites (fig. 5a, b).

\section{Weight at first maturity}

The weight at first maturity (when $50 \%$ of the individuals in the population showed mature gonads), for males and females, was $140 \mathrm{~g}$ at IN and $120 \mathrm{~g}$ at BT (fig. 6a, b).

\section{Temperature}

It was not possible to record water temperature at the IN sampling site. At the BT sampling site, temperature showed a seasonal variation and was inversely related to the GI. Maximum temperature $\left(23.0^{\circ} \mathrm{C}\right)$ was recorded in October and minimum $\left(14^{\circ} \mathrm{C}\right)$ in April (fig. $\left.5 b\right)$.

\section{Discussion}

It is difficult to measure the length of holothurids because of their ability to easily contract and expand due to the absence of skeleton and their soft body wall. This was verified in the case of $P$. parvimensis, since even though the specimens were allowed to rest for $30 \mathrm{~min}$ in the laboratory to recover their habitual size, they still continued to change in length in response to any stimulus (Conand 1990, 1993b; Wiedemeyer 1994; Pérez-Plascencia 1995; Espinoza-Montes 2000). We therefore only measured total weight and length as a reference of the total weight and size of the organisms and did not analyze these variables in depth. Implementing a minimum catch size based on the length of $P$. parvimensis is not recommendable, since it is not the best management option (Pérez-Ruzafa and Marcos-Diego 1985, Conand 1990).

On the other hand, BW is an accurate and reliable variable. Despite the shape and size acquired by the individuals, there

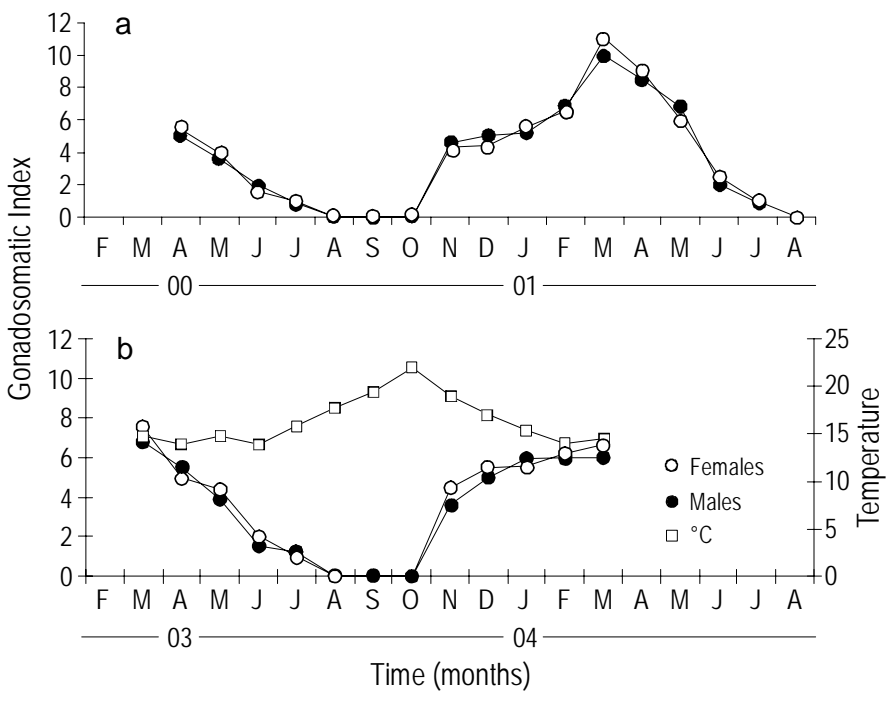

Figure 5. Mean monthly variation of the gonadosomatic index of Parastichopus parvimensis at (a) Isla Natividad and (b) Bahía Tortugas, and its relation to temperature $\left({ }^{\circ} \mathrm{C}\right)$

Figura 5. Variación del promedio mensual del índice gonadosomático de Parastichopus parvimensis en (a) Isla Natividad y (b) Bahía Tortugas, y su relación con la temperatura $\left({ }^{\circ} \mathrm{C}\right)$.

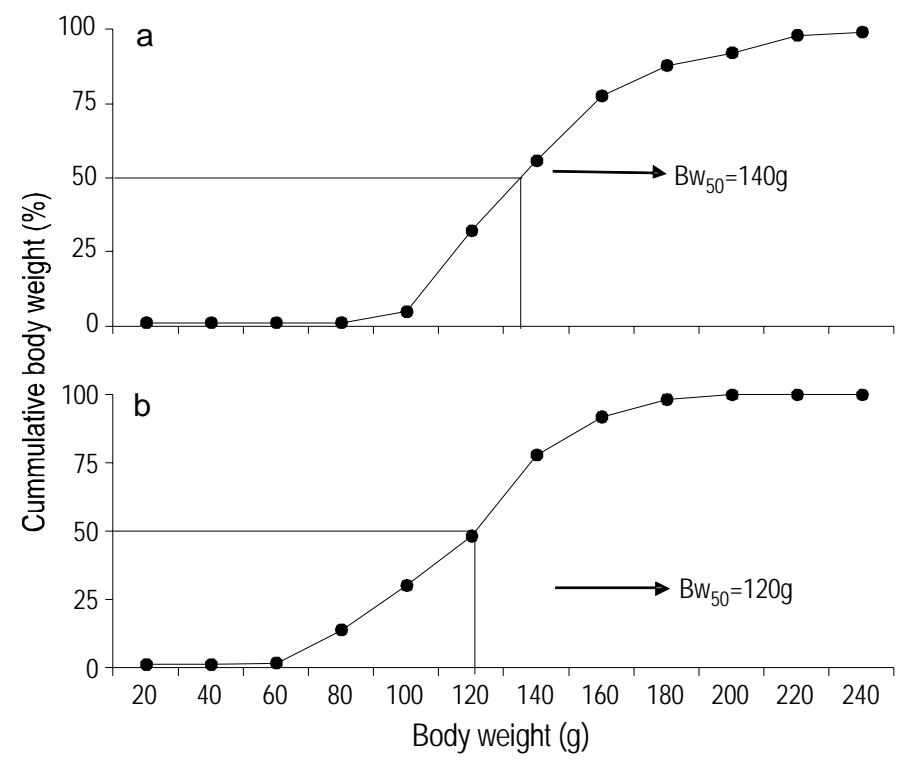

Figure 6. Weight at first maturity $\left(\mathrm{BW}_{50}\right)$ of Parastichopus parvimensis at (a) Isla Natividad and (b) Bahía Tortugas

Figura 6. Peso de primera madurez $\left(\mathrm{BW}_{50}\right)$ de Parastichopus parvimensis en (a) Isla Natividad y (b) Bahía Tortugas.

debido a que es un parámetro importante para el manejo del stock pues determina su valor comercial (Cameron y Fankboner 1986, Pérez-Plascencia 1995, Espinoza-Montes 2000).

Siguiendo los criterios anteriores (Cameron y Fankboner 1989) para determinar las características histológicas se pudo describir el desarrollo celular de la gónada y reconocer los 
was minimum variation between sexes and sites. A comparison of the mean BW values for males and females revealed no significant differences at either site; however, the BW values for IN were slightly higher than those for BT. Currently, BW is the biometric variable most used in studies on the reproductive biology and population dynamics of holothurids since it is an important stock management parameter, determining its commercial value (Cameron and Fankboner 1986, Pérez-Plascencia 1995, Espinoza-Montes 2000).

Following the above criteria (Cameron and Fankboner 1989), the histological characteristics of the gonadal cell development observed and the five stages determined are similar to those described for other temperate (Cameron and Fankboner 1989, Tapia-Vázquez et al. 1996, Espinoza-Montes 2000) and tropical (Nuño-Hermosillo 2003, Skarbnik-López 2006) holothurian species.

Parastichopus parvimensis showed an annual reproductive cycle at both IN and BT. Both males and females showed a marked reproductive seasonality at both sites in winter/spring (February/March). These results concur with that found for this species by Pérez-Plascencia (1995) at Bahía Todos Santos (Baja California) and Espinoza-Montes (2000) at IN. Cameron and Fankboner (1986) also observed this in P. californicus and indicated the the annual reproductive period is characteristic of most temperate-water species.

In table 2 we compare the ripe/spawning period observed for $P$. parvimensis in this study with that reported by other authors for other sites. A south-to-north latitudinal gradient can be observed for the reproductive season of this species. In the southern areas the ripe/spawning period occurs in winter/ spring and in the northern, in spring/summer. This gradient is probably due to different oceanographic conditions, environmental factors, latitude, or geographical distribution. Cameron and Fankboner (1986) indicate that many holothurids spawn in response to an increase in ambient light intensity; for example, $P$. californicus initiates spawning with the increase in daylight length and intensity, which means an increase in phytoplankton biomass, factors that could be possible inducers of latitudinal spawning. Pérez-Plascencia (1995) and Espinoza-Montes (2000) observed that these factors induced spawning in $P$. parvimensis in Bahía Todos Santos and at IN; hence, we consider that they could also be spawning inducers at IN and BT, but this was not evaluated.

The reproductive period of $P$. parvimensis was determined based on the histological analysis and the GI, which was an indicator of the seasonal reproductive behaviour. As this index can vary depending on the physiological condition of the organism, and on environmental (temperature) and feeding factors, the histological study was necessary to validate the reproductive activity. Both analyses are complementary and widely used (Engstrom 1980, Harriot 1985, Herrero-Pérezrul et al. 1999, Nuño-Hermosillo 2003). The monthly mean GI values for males and females from IN and BT revealed a similar behaviour. The GI began to increase in November when the cinco estadios observados en el presente estudio, éstos resultaron similares a los descritos para otras especies de holoturias de aguas templadas (Cameron y Fankboner 1989, TapiaVázquez et al. 1996, Espinoza-Montes 2000) y tropicales (Nuño-Hermosillo 2003, Skarbnik-López 2006).

Parastichopus parvimensis mostró un ciclo reproductivo anual tanto en IN como en BT. Tanto hembras como machos mostraron una marcada estacionalidad reproductiva en invierno/primavera (febrero/marzo) en ambas zonas. Estos resultados coinciden con lo reportado para esta especie por Pérez-Plascencia (1995) en Bahía Todos Santos (Baja California) y por Espinoza-Montes (2000) en IN. Cameron y Fankboner (1986) reportan lo mismo en $P$. californicus y señalan que el periodo de reproducción anual es característico de la mayoría de las especies de aguas templadas.

En la tabla 2 se compara el periodo de madurez y desove registrado para $P$. parvimensis en este estudio, con los registrados por otros investigadores en otros sitios. Se aprecia que la época de reproducción de esta especie presenta un gradiente latitudinal de sur a norte. En la zona sur el periodo de madurez/ desove es en invierno/primavera mientras que en el norte es en primavera/verano. Este gradiente probablemente se debe a las condiciones oceanográficas, a factores ambientales, a la latitud o a la distribución geográfica. Cameron y Fankboner (1986) indican que muchos holotúridos desovan en respuesta al incremento en la intensidad del régimen de luz ambiental, como $P$. californicus, que inicia su desove con el incremento de la duración e intensidad de la luz del día, lo que implica el incremento de la biomasa de fitoplancton, factores que pueden ser los posibles inductores del desove latitudinal. Pérez-Plascencia (1995) y Espinoza-Montes (2000) registraron que estos factores inducen el desove de P. parvimensis en Bahía Todos Santos y en IN, por lo que se considera que éstos podrían también ser los inductores de desove en IN y BT, pero ésto no fue evaluado.

El periodo de reproducción de $P$. parvimensis fue determinado con base en el estudio histológico y respaldado con la determinación de IG, que fue un indicador de la actividad y esfuerzo reproductivo estacional para esta especie, ya que los resultados indicaron el comportamiento reproductor de la especie. Sin embargo, es importante señalar que el IG es un índice que puede variar con el estado fisiológico del organismo, por factores ambientales (temperatura) y por la alimentación, por lo que resultaba necesario validar la actividad reproductora con el estudio histológico. Ambos estudios son complementarios y de uso generalizado (Engstrom 1980, Harriot 1985, HerreroPérezrul et al. 1999, Nuño-Hermosillo 2003). El promedio mensual del IG en hembras y machos de IN y BT reveló un comportamiento similar. El IG se incrementó a partir de noviembre, mes en el que la gónada aumentó de volumen y peso, coincidiendo con el inicio de la gametogénesis; posteriormente aumentó en enero y febrero, alcanzando los valores máximos en marzo y abril, cuando se registró la máxima madurez, y disminuyo en abril y mayo conforme avanzó el desove. Los valores más bajos de IG se observaron en junio y julio, meses en los que se incrementaron el post-desove y los 
Table 2. Comparison of the reproductive (ripe/spawning) period, weight at first maturity, and period during which viscera are absent in Parastichopus parvimensis from different sites.

Tabla 2. Comparación de los periodos de reproducción (madurez y desove), primera madurez y fenómeno fisiológico (ausencia estacional de vísceras) de Parastichopus parvimensis en otras localidades, con las encontradas en el presente estudio.

\begin{tabular}{|c|c|c|c|c|}
\hline Reference & Site & $\begin{array}{l}\text { Ripe/spawning } \\
\text { period }\end{array}$ & $\begin{array}{l}\text { First maturity } \\
\quad\left(\mathrm{BW}_{50}, \mathrm{~g}\right)\end{array}$ & $\begin{array}{c}\text { Seasonal } \\
\text { visceral absence }\end{array}$ \\
\hline Muscat (1982) & Santa Catalina Island, California, USA & May-June & - & September-October \\
\hline McEuen (1988) & California, USA & May-June & - & May-June \\
\hline Tapia-Vázquez et al. (1996) & $\begin{array}{l}\text { Bahía Todos Santos and Bahía del Rosario, } \\
\text { west coast of Baja California, Mexico }\end{array}$ & March-June & - & - \\
\hline Espinoza-Montes (2000) & Isla Natividad, Baja California Sur, Mexico & March-April & 122 & September-October \\
\hline This study & Isla Natividad, BCS, Mexico & February-May & 140 & August-October \\
\hline This study & Bahía Tortugas, BCS, Mexico & February-May & 120 & August-October \\
\hline
\end{tabular}

gonad increased in weight and volume, coinciding with the onset of gametogenesis. It increased in January and February, with maximum values in March and April, when maximum maturity was recorded, and then decreased in April and May when spawning advanced. The lowest GI values were recorded in June and July when the number of post-spawning and undifferentiated individuals increased. From August to October the mean GI value was zero because the organisms had entered the period of seasonal visceral absence. Based on these results, we ratify that $P$. parvimensis has a synchronous annual reproductive cycle. This pattern is similar to that found for P. parvimensis by Pérez-Plascencia (1995) in Bahía Todos Santos and by Espinoza-Montes (2000) also at IN. Synchronous reproduction has also been reported by Cameron and Fankboner (1986, 1989) in P. californicus; by Conand (1993a) in Stichopus variegatus; by Fajardo-León et al. (1995), Herrero-Pérezrul et al. (1999) and Nuño-Hermosillo (2003) in Isostichopus fuscus; and by Skarbnik-López (2006) in Holothuria (Selenkothuria) lubrica.

At BT, an inverse relationship was observed between the GI and water temperature at the sampling site. The reproductive event occurred in spring when the lowest temperatures of the study period were recorded. The highest temperatures were recorded in September and October, during the period when the organisms lacked internal organs. At BT, temperature played a significant role in the reproductive cycle.

The seasonal absence of viscera is a common phenomenon in species of the order Aspidochirota (Byrne 1985), and in this study it was clearly observed between August and October (in both sexes and at both sites). This physiological phenomenon has also been reported for other species of the genus Parastichopus. Some authors suggest that the absence of viscera is the result of autoevisceration (Yingst 1976, 1982; Dimock 1977; Muscat 1982), while others think that it is due to the reabsorption of internal organs (Fankboner and Cameron individuos indiferenciados. De agosto a octubre el IG fue cero porque los individuos entraron en el periodo de ausencia estacional de vísceras. Con base en estos resultados se ratifica que $P$. parvimensis presenta un ciclo reproductor anual sincrónico similar al encontrado por Pérez-Plascencia (1995) para esta misma especie en Bahía Todos Santos, y por Espinoza-Montes (2000) también en IN. También Cameron y Fankboner (1986, 1989) han reportado reproducción sincrónica en $P$. californicus; Conand (1993a) en Stichopus variegatus; Fajardo-León et al. (1995), Herrero-Pérezrul et al. (1999) y Nuño-Hermosillo (2003) en Isostichopus fuscus; y Skarbnik-López (2006) en Holothuria (Selenkothuria) lubrica.

En BT se observó una relación inversa entre IG y la temperatura del agua en la zona de muestreo. El evento reproductor fue en primavera con las temperaturas más baja del periodo de estudio, mientras que la temperatura más alta se registró en septiembre y octubre, cuando los individuos están en el periodo de ausencia de órganos internos. En BT la temperatura jugó un papel significativo en el ciclo reproductor.

La ausencia estacional de vísceras es un fenómeno común en los Aspidochirotas (Byrne 1985), y en este estudio se observó claramente entre agosto y octubre (en ambos sexos y áreas). En otras especies del género Parastichopus también se ha reportado este fenómeno fisiológico. Algunos investigadores sugieren que la ausencia de vísceras es el resultado de la autoevisceración (Yingst 1976, 1982; Dimock 1977; Muscat 1982), mientras que otros opinan que se debe a la reabsorción de los órganos internos (Fankboner y Cameron 1985, PérezPlascencia 1995, Espinoza-Montes 2000). Sin embargo, en el presente estudio este fenómeno se observó pero no se evaluó su causa.

Se estimó el peso de primera madurez como punto de referencia para el manejo del recurso, ya que éste es empleado como estrategia de decisión en el establecimiento de la época de veda (Pérez-Plascencia 1995, Espinoza-Montes 2000, 
1985, Pérez-Plascencia 1995, Espinoza-Montes 2000). We observed this phenomenon but did not analyze the cause.

Weight at first maturity was estimated to serve as reference for management purposes, since it is used in the decisionmaking process to establish the closed season (PérezPlascencia 1995, Espinoza-Montes 2000, Nuño-Hermosillo 2003). In BCS, the two most productive areas of $P$. parvimensis are IN and BT, so estimating weight at first maturity was important to augment the resource's state management criteria. Weight at first maturity (including both sexes) was slightly higher at IN than at BT. Espinoza-Montes (2000) reported a weight at first maturity (using BW) of $122 \mathrm{~g}$ for this species at IN; this value is slightly lower than that recorded in this study at IN and very close to that obtained at BT. Pérez-Plascencia (1995) reported a weight of $160 \mathrm{~g}$ and a minimum weight at first maturity of $120 \mathrm{~g}$, and considered that $P$. parvimensis could reproduce for the first time at the latter weight.

The information obtained in this study will be of use in the development of management strategies for $P$. parvimensis. We propose implementing two closed seasons: one from February to May to protect the reproductive event and another from August to October to safeguard the period when the internal organs are absent or atrophied, a physiological phenomenon of this species in the study areas.

\section{Acknowledgements}

We thank JA Espinoza-Montes, technician of the "Buzos y Pescadores de la Baja California” fishery cooperative society, and M Ramade-Villanueva, technician of the "Bahía Tortugas" cooperative society, and all the staff of these cooperatives for their help and logistical support.

English translation by Christine Harris.

\section{References}

Bell TA, Lighter DV. 1988. A Handbook of Normal Penaeid Shrimp. Histology. Allen Press. Kansas, 114 pp.

Byrne M. 1985. Evisceration behavior and the seasonal incidence of evisceration in the holothurians Eupentacta quinquesemita (Selenka). Ophelia 24: 75-90.

Cameron JL, Fankboner PV. 1986. Reproductive biology of the commercial sea cucumber Parastichopus californicus (Stimpson) (Echinodermata: Holothuroidea). I. Reproductive periodicity and spawning behavior. Can. J. Zool. 64: 168-175.

Cameron JL, Fankboner PV. 1989. Reproductive biology of the commercial sea cucumber Parastichopus californicus. II. Observations on the ecology of development, recruitment and the juvenile life stage. J. Exp. Mar. Biol. Ecol. 127: 43-67.

Clark HI. 1913. Echinoderms from Lower California with descriptions of new species. Bull. Mar. Sci. 32: 185-235.

Conand C. 1981. Sexual cycle of three commercially important holothurian species (Echinodermata) from the lagoon of New Caledonia. Bull. Mar. Sci. 31: 523-543.

Conand C. 1990. The fishery resources of Pacific island countries. FAO Fish. Tech. Pap. Part 2. Holothurians. FAO, Rome, 143 pp.
Nuño-Hermosillo 2003). En BCS las dos zonas más productivas de $P$. parvimensis son IN y BT, por lo que resultó importante estimar el peso de primera madurez para incrementar los criterios de manejo pesquero del recurso en ese estado. En IN el peso de primera madurez (incluyendo ambos sexos) fue ligeramente mayor al de BT. Espinoza-Montes (2000) reportó para esta especie un peso de primera madurez (utilizando PC) de $122 \mathrm{~g}$ en IN, que resulta poco menor al registrado en este estudio en IN y muy cercano al de BT. Pérez-Plascencia (1995) reporta un peso de 160 g y uno mínimo de primera madurez de 120 g, y consideró que en este último peso $P$. parvimensis podría reproducirse por primera vez.

En el presente estudio se obtuvo la información necesaria para proponer un plan de manejo pesquero de $P$. parvimensis que cuya táctica consista en implementar dos épocas de veda, una de febrero a mayo para proteger el evento reproductor y otra de agosto a octubre para salvaguardar el periodo de ausencia y atrofia de órganos internos, un fenómeno fisiológico que se observó en la especie en las zonas de estudio.

\section{Agradecimientos}

Expresamos nuestro agradecimiento a JA EspinozaMontes, técnico de la Sociedad Cooperativa de Producción Pesquera Buzos y Pescadores de la Baja California, y a M Ramade-Villanueva, técnico de la Sociedad Cooperativa de Producción Pesquera Bahía Tortugas, y al personal de ambas cooperativas por su colaboración y apoyo logístico.

Conand C. 1993a. Ecology and the reproductive biology of Stichopus variegatus, an Indopacific coral reef sea cucumber (Echinodermata: Holothuroidea). Bull. Mar. Sci. 52(3): 970-981.

Conand C. 1993b. Reproductive biology of the holothurians from the major communities of the New Caledonian Lagoon. Mar. Biol. 116: 439-450.

Dimock RV. 1977. Effects of evisceration on oxygen consumption by Stichopus parvimensis (Echinodermata, Holothuroidea). J. Exp. Mar. Biol. Ecol. 28: 125-132.

Engstrom AN. 1980. Reproductive cycles of Halodeima floridiana, Holothuria mexicana and their hybrids (Echinodermata: Holothuroidea) in southern Florida, USA. Int. J. Invertebr. Reprod. 2: 237-244.

Espinoza-Montes A. 2000. Ciclo reproductivo del pepino de mar Parastichopus parvimensis (HL Clarck, 1913) (Echinodermata, Holothuroidea) en Isla Natividad, Baja California Sur, México. Thesis, Universidad Autónoma de Guadalajara, 60 pp.

Fajardo-León MC, Turrubiates-Morales J. 2005. Distribución y densidad de Parastichopus parvimensis en la costa noroccidental de Baja California Sur. Simposio sobre Ciencias Pesqueras en México. Mayo 2005, La Paz, BCS, México.

Fajardo-León MC, Michel-Guerrero E, Vélez-Barajas JA, MassóRojas JA, Singh-Cabanillas J. 1995. Estructura poblacional y ciclo reproductor del pepino de mar Isostichopus fuscus (Ludwig 1875) en Santa Rosalía, Baja California Sur, México. Cienc. Pesq. 11: 45-53.

Fankboner PV, Cameron LJ. 1985. Seasonal atrophy of the visceral organs in a sea cucumber. Can. J. Zool. 631: 888-892.

Grant A, Tyler RA. 1983. The análisis of data in studies of invertebrate reproduction. I. Introduction and statistical analysis 
of gonad indices and maturity indices. Int. J. Invertebr. Reprod. 6: 259-269.

Harriot VJ. 1985. Reproductive biology of three congeneric sea cucumber species, Holothuria atra, $H$. impatiens y $H$. edulis, at Heron Reef in the Great Barrier Reef. Aust. J. Mar. Freshw. Res. 36: 51-57.

Herrero-Pérezrul MD, Reyes-Bonilla H, García-Dominguez F, CintraBuenrostro C. 1999. Reproduction and growth of Isostichopus fuscus (Echinodermata: Holothuroidea) in the southern Gulf of California, Mexico. Mar. Biol. 135: 521-532.

Martoja R, Martoja P. 1970. Técnica de Histología Animal. TorayMarson, Barcelona, 373 pp.

McEuen FS. 1988. Spawning behaviors of Northeast Pacific sea cucumbers (Holothuroidea: Echinodermata). Mar. Biol. 98: 565585.

Muñetón-Gómez MS, Villalejo-Fuerte M, García-Melgar G. 2000. Manual de Técnicas Histológicas Aplicadas a Organismos Marinos. Univ. Autónoma de Baja California Sur, La Paz, 81 pp.

Muscat A. 1982. Aspects of the biology of the sea cucumber Parastichopus parvimensis: A developing comercial fisheries. In: Planning and Management of California's Coastal Resources. U.S.C. Sea Grant Institutional Programs, 1981-1982. Trainee Rep., pp. 25-27.

Nuño-Hermosillo A. 2003. Ecología poblacional, ciclo reproductivo e historia de la pesquería del pepino de mar Isostichopus fuscus (Ludwig, 1875) (Echinodermata: Holothuroidea) en Bahía Chamela, Jalisco, México. M.Sc. thesis, Universidad de Guadalajara, México, 111 pp.

Pérez-Plascencia G. 1995. Crecimiento y reproducción del pepino de mar Parastichopus parvimensis en la Bahía de Todos Santos, Baja
California, México. M.Sc. thesis, Universidad Autónoma de Baja California, México, 67 pp.

Pérez-Ruzafa A, Marcos-Diego C. 1985. Técnicas de recolección y estudio en la clase Holoturoidea. I. Generalidades, sistemática, ecología, biología y comportamiento. An. Biol. 3 (Biol. Anim.): 13-35.

Skarbnik-López J. 2006. Ciclo reproductor de Holothuria (Selenkothuria) lubrica Selenka, 1867 (Echinodermata: Holothuroidea) en el sur de la Bahía de La Paz, BCS, México. Tesis de licenciatura. Universidad Autónoma de Baja California Sur, México, 67 pp.

Sokal R, Rohlf JH. 1995. Biometry. 3rd ed. WH Freeman \& Co., New York, 468 pp.

Tapia-Vázquez OM, Castro-González JJ, Valles-Ríos H. 1996. Madurez gonádica del pepino de mar Parastichopus parvimensis en la costa occidental de Baja California, México. Cienc. Pesq. 12: 5-12.

Tyler PA, Gage JD. 1983. The reproductive biology of Ypsilothuria talismani (Holothuroidea: Dendrochirota) from the NE Atlantic. J. Mar. Biol. Assoc. UK 63: 609-616.

Wiedemeyer WL. 1994. Biology of small juveniles of the tropical holothurian Actinopyga echinites: Growth, mortality, and habitat preferences. Mar. Biol. 120: 81-93.

Yingst JY. 1976. The utilization of organic matter in shallow marine sediments by an epibenthic deposit-feeding holothurian. J. Exp. Mar. Biol. Ecol. 23: 55-69.

Yingst JY. 1982. Factors influencing rates of sediment ingestion by Parastichopus parvimensis (Clark), an epibenthic deposit-feeding holothurian. Estuar. Coast. Shelf Sci. 141: 119-134.

Recibido en octubre de 2007; aceptado en marzo de 2008. 